\title{
ALASAN MENGAJUKAN GUGATAN \\ DI PENGADILAN TATA USAHA
}

\author{
Nama Mahasiswa : YUHARNEL \\ Email: yuharnel.padek@gmail.com
}

No. BP. 2010003600440

\section{Perguruan Tinggi : UNIVERSITAS EKA SAKTI PADANG}

\section{A. PENDAHULUAN}

Sebagai sarana kontrol sosial dalam masyarakat, hukum yang bersifat dinamis sangatlah dibutuhkan untuk memenuhi kebutuhan dan keadilan dalam masyarakat.Selain itu, hukum juga harus selalu mengikuti perkembangan zaman dan tidak boleh berorientasi pada masa lampau. Hukum harus dijalankan seadil-adilnya agar dapat memberikan pengayoman yang baik kepada masyarakat dan memberikan dorongan kepada masyarakat agar mereka dapat memperoleh kehidupan yang lebih baik.

Dalam melaksanakan fungsi keadilan dari Pengadilan Tata Usaha Negara harus dilakukan sesuai dengan peraturan perundang-undangan yang berlaku. Secara umum, tujuan dari Peradilan Tata Usaha Negara ini sendiri adalah untuk memberikan pelayanan apabila terdapat suatu benturan kepentingan, perselisihan atau sengketa yang terjadi antara Badan atau Pejabat Tata Usaha Negara dengan masyarakat. Peradilan Tata Usaha ini adalah salah satu dari beberapa peradilan yang ada di Indonesia dan memiliki kewenangan untuk memproses ataupun menyelesaikan masalah suatu sengketa di bidang Tata Usaha Negara. Peradilan Tata Usaha Negara ini diatur berdasarkan Undang-Undang No.5 Tahun 1986 tentang Peradilan Tata Usaha Negara. Namun, Undang- 
Undang No. 5 Tahun 1986 telah diubah sebanyak dua kali, yaitu perubahan pertama oleh Undang-Undang Nomor 9 Tahun 2004 dan perubahan kedua oleh Undang-Undang Nomor 51 Tahun 2009.Undang-Undang Peradilan Tata Usaha ini sendiri mempunyai dua opsi penyelesaian perkara bidang sengketa Tata Usaha Negara, yaitu melalui upaya administrasi yang penyelesaiannya masih dalam ranah administrasi pemerintahan itu sendiri dan melalui gugatan ke pengadila Tata Usaha Negara. Tidak seperti Peradilan Umum pada umumnya, karena hakim dalam Peradilan Tata Usaha ini lebih bersifat aktif untuk memproses persidangan agar mendapatkan suatu kebenaran materiil dan gugatan TUN bukan berarti menunda dilaksanakannya suatu Keputusan Tata Usaha Negara (KTUN) yang disengketakan. Adapun subjek atau pihak yang dapat berperkara di dalam Pengadilan Tata Usaha Negara adalah pihak tergugat dan pihak penggugat. Di mana pihak tergugat merupakan seorang atau Badan Hukum Perdata yang kepentingannya telah dirugikan dan pihak tergugat sendiri merupakan badan atau pejabat Tata Usaha Negara yang mengeluarkan keputusan berdasarkan wewenang yang ada padanya atau yang diberikan kepadanya. Proses acara yang akan dilakukan dalam Pengadilan Tata Usaha Negara harus berdasarkan Asas - Asas Umum Pemerintahan yang Baik yang telah ditunjukkan pada Pasal 53 ayat (2) Undang - Undang Pengadilan Tata Usaha Negara.

\section{B. PEMBAHASAN}

Tata Usaha Negara adalah administrasi negara yang juga melakukan fungsi untuk menyelenggarakan urusan pemerintahan pusat dan daerah. Selanjutnya, Keputusan Tata Usaha Negara merupakan suatu objek dalam Peradilan Tata Usaha Negara dan memiliki pengertian sebagai suatu penetapan 
tertulis yang dikeluarkan oleh Badan atau Pejabat Tata Usaha Negara yang di dalamnya terdapat tindakan hukum Tata Usaha Negara yang didasarkan pada peraturan perundang-undangan yang berlaku dan bersifat konkret, individual, dan final yang dapat menimbulkan akibat hukum bagi seseorang atau bagi badan hukum perdata. Dalam hubungan antara seseorang atau badan hukum perdata pasti akan terdapat beberapa permasalahan atau yang disebut dengan Sengketa Tata Usaha Negara yang dapat terjadi di pusat maupun di daerah atas akibat keluarnya Keputusan Tata Usaha Negara termasuk sengketa kepegawaian berdasarkan peraturan perundang-undangan yang berlaku. Di dalam sengketa bidang Tata Usaha Negara, pasti terdapat suatu Gugatan Tata Usaha Negara yang berupa permohonan tuntutan yang ditujukan kepada badan atau Pejabat Tata Usaha Negara dan diajukan ke pengadilan demi mendapatkan suatu keputusan. Beberapa pengertian di atas dapat ditemui dalam Pasal 1 Undang-undang Nomor 5 Tahun 1986, diuraikan tentang pengertian-pengertian yang berkaitan dengan Peradilan Tata Usaha Negara.

Ketika melakukan proses acara dalam Pengadilan Tata Usaha Negara, terkait alasan pengajuan gugatan harus didasari dengan Asas-Asas Umum Pemerintahan yang Baik atau yang dikenal dengan AAUPB. Hal tersebut bertujuan agar alasan pengajuan gugatan selain Keputusan Tata Usaha Negara yang sedang disengketakan bertentangan dengan Peraturan perundang-undangan Asas-Asas Umum Pemerintahan yang baik dapat digunakan sebagai alasan pengajuan

gugatan Tata Usaha Negara adalah kepastian hukum, tertib penyelenggaraan Negara, keterbukaan, proporsionalitas, profesionalitas dan akuntabilitas. 
Selanjutnya, dalam melaksanakan suatu putusan pengadilan, terdapat kewenangan untuk melakukan pemeriksaan terhadap Badan atau Pejabat Tata Usaha Negara untuk melakukan putusan melalui adanya uang paksa dan sanksi administratif. Kedua hal tersebut akhirnya mengubah sistem eksekusi putusan Pengadilan Tata Usaha Negara yang semula dari floating execution dan menjadi fixed execution atau yang disebut eksekusi di mana pelaksanaannya bisa dipaksakan oleh pengadilan melalui sarana-sarana pemaksa yang diatur dalam peraturan perundang-undangan. Hal tersebut memiliki tujuan untuk menyelesaikan adanya sengketa Tata Usaha Negara. Sebagaimana kita ketahui bahwa Keputusan Tata Usaha Negara memiliki asas contractus actus yang mengungkapkan bahwa penarikan kembali atau perubahan suatu keputusan harus pula memenuhi suatu persyaratan seperti pada awal keputusan tersebut dibuat. Hal-hal itu telah tercantum pada Undang-Undang Nomor 51 Tahun 2009 tentang Perubahan Kedua Atas Undang-Undang Nomor

5 Tahun 1986 Tentang Peradilan Tata Usaha Negara bahwa PTUN memiliki tugas dan wewenang untuk memeriksa, memutus, dan menyelesaikan sengketa Tata Usaha Negara pada tingkat pertama.

Adapun subjek atau pihak-pihak yang menjadi bagian dari Peradilan Tata Usaha adalah penggugat dan tergugat. Penggugat adalah seorang atau badan hukum perdata yang merasa kepentingannya telah dirugikan akibat dikeluarkannya Keputusan Tata Usaha Negara, sesuai dengan Pasal 53 ayat (1) UU PTUN. Jadi, pihak yang dapat mengajukan gugatan kepada Pengadilan Tata Usaha Negara adalah: 
1. Orang yang merasa kepentingannya dirugikan oleh suatu Keputusan Tata Usaha Negara; dan

2. Badan Hukum Perdata yang merasa kepentingannya dirugikan oleh suatu Keputusan Tata Usaha Negara.

Selanjutnya, Tergugat merupakan jabatan yang ada pada Badan Tata Usaha Negara yang mengeluarkan Keputusan Tata Usaha Negara berdasarkan wewenang dari Badan Tata Usaha itu atau wewenang yang dilimpahkan kepadanya. Jadi, dapat disimpulkan bahwa bukanlah orangnya secara pribadi yang digugat, tetapi jabatan yang melekat pada orang tersebut.

Gugatan sengketa yang akan diajukan kepada Pengadilan Tata Usaha harus berbentuk tertulis karena hal itulah yang akan menjadi pondasi bagi pengadilan dan para pihak itu sendiri dalam pemeriksaan terhadap sengketa Tata Usaha Negara yang bersangkutan. Di mana isi dari tuntutan gugatan Tata Usaha Negara itu sendiri telah ditetapkan dalam Undang -Undang Peradilan Tata Usaha Negara, yaitu hanya terdiri dari tuntutan pokok yang bermaksud agar Keputusan Tata Usaha Negara yang merugikan dirinya dianggap batal atau tidak sah, dengan atau tanpa disertai tuntutan ganti rugi dan/atau rehabilitasi. Hal tersebutlah yang menjadi alasan mengajukan Gugatan dalam Pengadilan Tata Usaha yang telah diatur pada Pasal 52 ayat (1) UU PTUN. Selain itu, alasan atau dasar gugatan ditunjukkan pada Pasal 53 ayat (2) UU PTUN, yang berbunyi :

"Alasan - alasan yang dapat digunakan dalam gugatan sebagaimana dimaksud dalam ayat (1) adalah :

1. Keputusan Tata Usaha Negara yang digugat tersebut bertentangan dengan peraturan perundang-undangan yang berlaku.

2. Keputusan Tata Usaha Negara yang digugat tersebut bertentangan dengan asas - asas umum pemerintahan yang baik (AAUPB)."

3. Badan atau pejabat Tata Usaha Negara pada waktu mengeluarkan 
sebagai mana dimaksud dalam ayat (1) telah menggunakan wewenangnya untuk tujuan lain.

Syarat-syarat untuk mengajukan surat gugatan secara substantif harus memuat nama, kewarganegaraan, tempat tinggal, pekerjaan penggugat atau kuasanya, nama jabatan dan tempat kedudukan tergugat,dasar gugatan dan hal-hal lain yang dimintakan diputuskan oleh pengadilan,keabsahan perwakilan, bukti obyek gugatan.

Keputusan Tata Usaha Negara dapat dikatakan bertentangan dengan peraturan perundang-undangan apabila keputusan tersebut bertentangan dengan peraturan perundang-undangan yang sifatnya Material atau Substansial, seperti ketentuan peraturan perundang-undangan yang menentukan bahwa sebelum keputusan pemberhentian dikeluarkan, pegawai yang bersangkutan harus diberi kesempatan untuk membela diri. Tetapi, apabila terdapat Keputusan Tata Usaha Negara yang tidak memberikan kesempatan untuk membela diri sebelum Keputusan TUN dikeluarkan, maka Keputusan Tata Usaha Negara itu bertentangan dengan ketentuan yang terdapat dalam perundang-undangan yang sifatnya prosedural ataupun formal. Selain itu, Keputusan Tata Usaha Negara dapat dikatakan bertentangan dengan peraturan perundang-undangan apabila keputusan tersebut bertentangan dengan peraturan perundang-undangan yang sifatnya substansial, seperti keputusan yang berada dalam tingkat banding administratif yang salah dan menyatakan bahwa gugatan penggugat diterima atau tidak diterima.

Ketika mengajukan suatu gugatan, harus selalu memperhatikan tenggang waktu atau kapan seseorang maupun badan hukum perdata dapat mengajukan gugatannya tersebut. Hal tersebut telah tercantum pada Pasal 55 Undang-Undang 
Peradilan Tata Usaha yang berbunyi :

" Gugatan dapat diajukan hanya dalam tenggang waktu Sembilan puluh hari terhitung sejak diterimanya atau diumumkannya keputusan Badan atau Pejabat Tata Usaha Negara.”

Jadi, ketentuan itu berarti bahwa sesudah tenggang waktu Sembilan puluh hari dan telah terhitung saat diterima atau diumumkannya keputusan Badan atau Pejabat TUN yang dinyatakan tidak boleh diterima oleh pengadilan dan keputusan Tata Usaha Negara tersebut telah dianggap melawan hukum atau merugikan orang atau badan hukum perdata yang telah dikatakan sah dan tidak diubah lagi melalui proses hukum.Tanggal diterimanya gugatan oleh Panitera Pengadilan TUN dianggap sebagai tanggal diajukannya gugatan kepada Pengadilan yang berwenang, agar tidak melewati tenggang waktu pengajuan gugatan. Apabila lewatnya dalam mengajukan gugatan dapat mengakibatkan gugatan tidak diterima atau kadaluarsa. Para pihak yang bersengketa masingmasing dapat didampingi atau diwakili oleh seorang atau beberapa orang kuasa, pemberian kuasa dapat dilakukan dengan surat kuasa atau lisan di persidangan. Surat Kuasa yang dibuat di luar negeri bentuknya harus memenuhi persyaratan d i negara yang bersangkutan dan diketahui oleh Perwakilan Republik Indonesia di negara tersebut, serta kemudian diterjemahkan ke dalam Bahasa Indonesia oleh penerjemah resmi. Sesuai dengan pasal 54 UU PTUN menegaskan alamat melakukan gugatan dirumuskan sebagai berikut;

1. Tempat kedudukan tergugat.

2. Tempat kedudukan salah satu badan atau pejabat Tata Usaha Negara.

3. Tempat kediaman penggugat.

4. Pengadilan di Jakarta. 


\section{PENUTUP}

Peradilan Tata Usaha Negara (PTUN) merupakan peradilan yang ada di Indonesia yang memiliki tujuan untuk melayani apabila terdapat suatu kepentingan yang berbenturan, adanya perselisihan atau sengketa yang terjadi di antara Badan atau Pejabat Tata Usaha Negara dengan masyarakat baik di tingkat pusat maupun daerah. Selain itu, kewenangan dari Peradilan Tata Usaha ini sendiri adalah untuk menyelesaikan masalah atau sengketa dalam ranah Tata Usaha Negara. Seseorang atau badan hukum perdata yang merasa kepentingannya dirugikan oleh suatu Keputusan Tata Usaha Negara dapat mengajukan gugatan tertulis kepada pengadilan yang berwenang. Dalam gugatan tertulis tersebut, berisi suatu alasan gugatan di mana gugatan itu harus berisi tuntutan agar Keputusan Tata Usaha Negara yang disengketakan itu dinyatakan batal atau tidak sah, dengan atau tanpa disertai tuntutan ganti rugi dan/atau rehabilitasi. Gugatan tertulis itu berisi tuntutan pokok yang bertujuan agar Keputusan Tata Usaha Negara yang merugikan dirinya dianggap batal atau tidak sah, dengan atau tanpa disertai tuntutan ganti rugi dan/atau rehabilitasi. Alasan mengajukan Gugatan dalam Pengadilan Tata Usaha telah diatur pada Pasal

52 ayat (1) UU PTUN dan pada Pasal 53 ayat (2) UU PTUN. Alasan tersebut berupa Keputusan Tata Usaha Negara yang digugat tersebut harus bertentangan dengan peraturan perundang-undangan yang berlaku dan Keputusan Tata Usaha Negara yang digugat tersebut bertentangan dengan asas - asas umum pemerintahan yang baik (AAUPB). 


\section{DAFTAR PUSTAKA}

Darmini Roza dan Laurensius Arliman S Peran Pemerintah Daerah Di Dalam Melindungi Hak Anak Di Indonesia, Masalah-Masalah Hukum, Volume 47, Nomor 1, 2018.

Laurensius Arliman S, Komnas HAM dan Perlindungan Anak Pelaku Tindak Pidana, Deepublish, Yogyakarta, 2015.

Laurensius Arliman S, Penguatan Perlindungan Anak Dari Tindakan Human Trafficking Di Daerah Perbatasan Indonesia, Jurnal Selat, Volume 4,Nomor 1, 2016.

Laurensius Arliman S, Ilmu Perundang-Undangan Yang Baik Untuk Negara Indonesia, Deepublish, Yogyakarta, 2019.

Laurensius Arliman S, Isdal Veri, Gustiwarni, Elfitrayenti, Ade Sakurawati, Yasri, Pengaruh Karakteristik Individu, Perlindungan Hak Perempuan Terhadap Kualitas Pelayanan Komnas Perempuan Dengan Kompetensi Sumber Daya Manusia Sebagai Variabel Mediasi, Jurnal Menara Ekonomi: Penelitian dan Kajian Ilmiah Bidang Ekonomi, Volume 6, Nomor 2, 2020.

Undang-Undang Dasar 1945, Jurnal Lex Librum, Volume 6, Nomor 2 Juni 2020, http://dx.doi.org/10.46839/lljih.v6i2.151.

Laurensius Arliman S, Kedudukan Lembaga Negara Independen Di Indonesia Untuk Mencapai Tujuan Negara Hukum, Kertha Semaya Journal Ilmu Hukum, Volume 8, Nomor 7, 2020.

Laurensius Arliman S, Pelaksanaan Assesment Oleh Polres Kepulauan Mentawai Sebagai Bentuk Pelaksanaan Rehabilitasi Bagi Pecandu Dan Korban Penyalahgunaan Narkotika, Jurnal Muhakkamah, Volume 5, Nomor 1, 2020.

Laurensius Arliman S, Aswandi Aswandi, Firgi Nurdiansyah, Laxmy Defilah, Nova Sari Yudistia, Ni Putu Eka, Viona Putri, Zakia Zakia, Ernita Arief, Prinsip, Mekanisme Dan Bentuk Pelayanan Informasi Kepada Publik Oleh Direktorat Jenderal Pajak, Volume 17, No Nomor, 2020.

Larensius Arliman S, Koordinasi PT. Pegadaian (Persero) Dengan Direktorat Reserse Narkoba Polda Sumbar Dalam Penimbangan Barang Bukti Penyalahgunaan Narkotika, UIR Law Review, Volume 4, Nomor 2, 2020, https://doi.org/10.25299/uirlrev.2020.vol4(1).3779.

Laurensius Arliman S, Tantangan Pendidikan Kewarganegaraan Pada Revolusi 4.0, Ensiklopedia Sosial Review, Volume 2, Nomor 3, 2020.

Muhammad Afif dan Laurensius Arliman S, Protection Of Children's Rights Of 
The Islamic And Constitutional Law Perspective Of The Republic Of Indonesia, Proceeding: Internasional Conference On Humanity, Law And Sharia (Ichlash), Volume1, Nomor 2, 2020.

Otong Rosadi dan Laurensius Arliman S, Urgensi Pengaturan Badan Pembinaan Idelogi Pancasila Berdasarkan Undang-Undang Sebagai State Auxiliary Bodies yang Merawat Pancasila dalam Perspektif Hak Asasi Manusia, Prosiding Konferensi Nasional Hak Asasi Manusia, Kebudayaan dan Tujuan Pembangunan Berkelanjutan Indonesia pada Masa Pandemi Covid-19: Tantangan untuk Keilmuan Hukum dan Sosial Volume 1, Universitas Pancasila, Jakarta, 2020. 